\title{
Penggunaan Multi Media untuk Meningkatkan Efektivitas Pesan Khutbah Jumat
}

\author{
Oleh Rendra Widyatama, SIP., M.Si \\ Program Studi Ilmu Komunikasi, Universitas Ahmad Dahlan \\ (rendrawidyatama@yahoo.com Hp. 08156852967)
}

\begin{abstract}
Abstrak
Di kalangan umat Islam di seluruh dunia, termasuh Indonesia, khutbah jumat merupakan aktivitas rutin. Disebut rutin, karena ibadah tersebut diselenggarakan secara teratur tiap hari jumat. Ibadah ini wajib dilakukan oleh ummat Islam laki-laki yang sudah baliq. Seperti halnya dengan ibadah shalat jumat, penyampaian khutbah jumat juga merupakan aktivitas rutin bagi para khatib. Indikator rutinitas dapat dilihat dari aktivitas komunikasi yang dilakukan, yaitu cenderung monoton, tidak dipersiapkan secara memadai, dan tidak menggunakan bantuan media apapun. Khatib hanya memenuhi rukun dan syarat syah khutbah sehingga terkesan tidak memperdulikan respon jamaah. Penyampaian pesan khutbah jumat dengan metode seperti itu, jamaah tidak terlihat menyimak nasehat khutbah. Dari banyak pengamatan, jamaah jumat banyak yang tertidur pada saat khutbah sampai ibadah tersebut dimulai. Keadaan ini jelas membuat pesan khutbah tidak efektif. Sehubungan dengan hal tersebut, khatib dan takmir masjid perlu melakukan inovasi kreatif atas khutbah jumat. Salah satu cara adalah dengan menggunakan multimedia sebagai alat bantu penyampaian pesan sehingga khutbah jumat dapat lebih menarik dan efektif.
\end{abstract}

Kata Kunci: Multimedia, Komunikasi, Pesan yang Efektif, Khutbah Jumat.

\section{A. Pendahuluan}

Salah satu ibadah wajib bagi umat Islam pria dewasa adalah menjalankan shalat jumat. Seperti namanya, ibadah ini dilakukan tiap hari jumat. Ibadah shalat dua rakaat ini memiliki keistimewaan, karena ia menggantikan kewajiban shalat dhuhur yang berjumlah empat rakaat, serta merupakan salah satu shalat wajib yang dikerjakan secara berjamaah.

Dasar hukum shalat jumat dituliskan oleh Allah SWT dalam surat Al Jumu'ah 62:9, yang bila diterjemahkan berarti "Wahai orang-orang yang beriman, apabila kamu diseru untuk melaksanakan shalat pada hari jumat, maka besegeralah mengingat Allah dan tinggalkanlah jual beli, dan itu lebih baik bagi kamu jika kamu mengetahui."

Surat Al Jumu'ah 62:9 tersebut secara jelas menegaskan bahwa shalat jumat merupakan ibadah wajib bagi tiap muslim laki-laki yang sudah dewasa (akilbaliq). Kewajiban ini bahkan dikategorikan sebagai fardu 'ain, yaitu kewajiban yang dikenakan bagi semua umat Islam berjenis kelamin pria yang telah dewasa, tanpa dapat diwakilkan. Karena bersifat wajib, maka bagi mereka yang melanggar akan menanggung dosa berupa hukuman neraka.

Selain tercantum dalam Al Qur'an, kewajiban shalat Jumat juga disampaikan dalam beberapa hadits shohih (yaitu hadist yang disampaikan oleh perawai yang kuat), antara lain disampaikan oleh HR Muslim, HR. Abu Daud, dan Al-Hakim. HR Muslim menyebut bahwa "hendaklah orang-orang itu berhenti dari meninggalkan salat Jum'at atau kalau tidak, Allah akan menutup hati mereka kemudian mereka akan menjadi orang yang lalai." Selain itu, dalam hadist Muslim, juga dikatakan bahwa; "Sungguh aku berniat 
menyuruh seseorang (menjadi imam) salat bersama-sama yang lain, kemudian aku akan membakar rumah orang-orang yang meninggalkan shalat Jum'at."

Dalam HR. Abu Daud dan Al-Hakim, keduanya merupakan hadits shahih, disampaikan bahwa; "Shalat Jum'at itu wajib bagi tiap-tiap muslim, dilaksanakan secara berjama'ah terkecuali empat golongan, yaitu hamba sahaya, perempuan, anak kecil dan orang yang sakit."

Dari landasan ayat Al-Quran dan hadis tersebut di atas, disimpulkan bahwa ibadah shalat jumat merupakan kewajiban bagi tiap individu laki-laki beragama Islam yang sudah dewasa dan harus dijalankan pada tiap hari Jumat sepanjang hidupnya.

Dalam pelaksanaannya, ibadah jumat wajib didahului dengan penyampaian pesan atau nasehat kebaikan dari khatib. Istilah populer penyampaian pesan kebaikan tersebut sering disebut dengan khutbah jumat. Penyampaian khutbah jumat merupakan salah satu syarat syah shalat Jum'at. Berarti, tidak akan ada shalat jumat tanpa khutbah jumat. Dalam sebuah hadits, diriwayatkan sebagai oleh Muslim yaitu dari lbnu Umar berknta, " Rasulullah saw. berkhotbah pada hari Jum'at sambil berdiri kemudian duduk kemudian berdiri. (H.R. Muslim: 1420).

Shalat jumat merupakan aktivitas rutin, sehingga penyampaian khutbah jumat juga cenderung dianggap sebagai rutinitas. Karena rutin banyak khatib yang tidak mempersiapkan khutbahnya dengan baik. Takmir atau pengurus masjid juga jarang melakukan persiapan yang cukup untuk penyelenggaraan khutbah jumat. Takmir juga tidak menyediakan alat bantu bagi khatib bagi kelancaran penyampaian khutbah jumat, yang lebih banyak lagi, selain pengeras suara. Di beberapa masjid kecil, bahkan alat bantu pengeras suara juga tidak tersedia.

Pergantian khotib jumat dalam waktu yang mepet dan mendadak, juga sering dilakukan karena berbagai alasan. Karena merupakan khotib pengganti dan tidak memiliki waktu yang cukup untuk melakukan persiapan, seringkali khutbah dilakukan tanpa fokus tema tertentu. Khatib pengganti menyampaikan khutbah hanya berdasarkan kebiasaan dan hafalan saja. Materi khutbah banyak diperoleh dari pengalaman seharihari maupun dicari di berbagai buku tentang khutbah jumat yang banyak dijumpai di pasaran. Akhirnya khatib tidak mampu menampilkan tema yang menarik. Asal memenuhi syarat syah khutbah, dianggap sudah cukup.

Dalam praketknya, meski merupakan khatib utama, dalam banyak pengamatan, khutbah jumat yang disampaikan cenderung dilakukan hanya sekedar memenuhi syarat syah ibadah shalat jumat. Akibatnya, pesan yang diberikan cenderung formalistik dengan metode ceramah seadanya dimana khotib tidak memperhatikan respon jamaah. Kondisi ini mengakibatkan jamaah sholat jumat mendengarkan khutbah secara sambil lalu, tidak fokus, bahkan banyak pula yang tertidur meski dalam posisi duduk.

Fenomena jamaah yang "mendengarkan" khutbah jumat seperti itu, jelas tidak dapat nilai apakah mereka memang mendengarkan pesan-pesan dari khotib dengan serius ataukah tidak. Bisa jadi, mereka tidak memperhatikan nasehat kebaikan dari khotib, melainkan sekedar menunggu waktu dilaksanakannya shalat jumat. Dari observasi partisipatoris atas shalat jumat di berbagai tempat masjid, sangat diragukan bahwa ummat mendengarkan khutbah jumat dengan serius. Lebih banyak dari mereka yang tertunduk sambil memejamkan mata, tidak dapat diketahui apa yang sedang mereka pikirkan. 
Diterbitkan oleh Fakultas Sastra dan Budaya

Universitas Ahmad Dahlan Yogyakarta

Sebagian lagi lainnya nyata-nyata tertidur, meski dalam posisi terduduk. Sangat jarang, jamaah shalat jumat yang menegakkan kepala dan memusatkan perhatian dan pandangannya pada khatib yang menyampaikan ceramah.

Atas fenomena tersebut di atas, tentu penyampaian khutbah jumat cukup disayangkan. Pesan kebaikan yang diserukan oleh khotib tidak dapat mencapai tujuan. Dengan kata lain, pesan khutbah menjadi tidak efektif. Untuk itu, perlu dilakukan terobosan guna meningkatkan efektivitas pesan. Yaitu terobosan yang kreatif namun tidak mengurangi apalagi membatalkan syarat syah khutbah dan shalat jumat itu sendiri. Salah satu terobosan tersebut adalah dengan menggunakan bantuan multimedia, dimana khatib menyampaikan pesan kebaikan dengan disertai dengan alat bantu multi media. Melalui multimedia yang bersifat audio dan visual ini, diharapkan jamaah shalat jumat akan memberikan perhatian yang lebih tinggi pada pemberian ceramah dari khatib.

\section{B. Pembahasan}

Shalat jumat merupakan momentum istimewa. Sebab, forum ini mampu mengumpulkan massa jumlah dalam jumlah cukup banyak. Meski ada banyak pendapat tentang jumlah peserta jamaah, namun karena dilakukan secara berulang setiap minggu selama sepanjang tahun, maka jumlah orang yang terlibat dalam shalat jamaah tersebut sangat bsesar. Oleh karena itu, untuk mensosialisasikan sebuah pesan, maka dapat dilakukan dalam waktu cepat bila melalui forum khutbah jumat. Takmir masjid tidak perlu sulit mengumpulkan orang-orang untuk berkumpul. Takmir (pengurus) masjid cukup menyiapkan tempat lalu mengumandangkan adzan, maka umat muslim akan berbondong-bondong datang.

Berkumpulnya jamaah dalam shalat jumat tersebut sebenarnya menjadi kesempatan yang menguntungkan untuk menyampaikan pesan pada khalayak banyak, tanpa sulit mengerahkan massa. Menurut sensus 2013 (http://www.bps.go.id) jumlah pria dewasa seluruh Indonesia sebanyak sekitar $88,259,764$ orang. Bila umat Islam Indonesia sebanyak $85,2 \%$, maka, diasumsikan akan ada $75,197,318$ orang pria dewasa yang mendatangi masjid setiap minggunya untuk shalat jumat. Bila seorang akan menyampaikan pesan tertentu untuk ditujukan pada 75,197,318 orang dalam satu hari tanpa melalui media massa, maka pelaksanaan shalat jumat merupakan forum yang dapat diandalkan.

Namun kesempatan shalat jumat tersebut dapat terbuang begitu saja bila pesan tidak disiapkan dengan baik oleh khotib. Persiapan tersebut meliputi isi pesan, metode penyampaian pesan, dan teknik pendekatan penyampaian pesan. Bila khutbah jumat sering berkesan hanya sekedar menggugurkan syarat wajib dan syah khutbah, sehingga berlangsung datar, tidak menarik, nonoton, bahkan menjemukan, maka perlu diubah menjadi ceramah yang menarik minat jamaah untuk memperhatikan.

Pada umumnya, dalam pelaksanaan shalat jumat, jamaah tertidur selama khutbah berlangsung. Akibatnya pesan tidak mampu menghasilkan dampak sesuai yang diharapkan. Pesan dakwah pantas dipertanyakan efektivitasnya. Dengan kata lain, komunikasi khutbah jumat tidak berhasil dengan efektif bila khutbah jumat disampaikan secara monoton dan tidak menarik. Oleh karena itu, cara-cara penyampaian pesan khotbah jumat yang dilakukan secara konfensional, perlu diubah dengan cara yang lebih kreatif. 


\section{Syarat Shalat Jumat}

Syarat shalat Jum'at meliputi syarat wajib dan syarat sah shalat. Shalat jumat merupakan ibadah wajib bagi tiap individu pria beragama Islam yang sudah dewasa. Kewajiban bagi tiap umat muslim tersebut dalam agama Islam disebut dengan fardlu ain (Amir Syarifuddin, 2010:33). Yaitu kewajiban yang harus ditanggung oleh setiap orang, tanpa dapat diwakilkan. Karena ibadah wajib, maka pengingkaran atasnya, akan dikenakan dosa dengan hukuman neraka. Saleh Al-Fauzan (2006:195-198) menuliskan tentang syarat shalat jumat, yaitu sebagai berikut:

\section{a. Syarat Wajib Shalat Jumat}

Mendirikan shalat Jum'at wajib dilakukan apabila jumlah peserta shalat jumat memenuhi sejumlah persyaratan yaitu; beragama Islam; sudah balig (dewasa); sehat akal (tidak gila); muslim laki-laki (perempuan tidak wajib); sehat badan dan bermukim (tidak sedang bepergian, musafir tidak wajib).

b. Syarat Syah Shalat Jum'at,

Sementara itu, syarat syah shalat jum'at harus terpenuhi syarat sebagai berikut:

1) Dilaksanakan di tempat-tempat yang sudah tetap. Tentang masalah tempat, mayoritas ulama (Hanafiyah, Syafiiyah, dan Hambali) berpendapat, jumatan tidak harus dilakukan di masjid kecil atau masjid jami' (http://www.konsultasisyariah.com/ bolehkah-sholat-jumat-di-kantor/). Menurut mayoritas ulama, shalat jum'at bisa dilakukan di masjid, di dalam bangunan atau di tempat-tempat lainnya. Umar bin Khottob pernah mengirim surat kepada penduduk Bahrain yang isinya, "Lakukanlah shalat jum'at di tempat mana saja kalian berada." (Riwayat Ibnu Abu Syaibah dan menurut Ahmad sanadnya baik). Dalam QS. Al Baqoroh (185), Allah menghendaki kemudahan bagimu, dan tidak menghendaki kesukaran bagimu. Selain itu, dalam Al Hajj ayat 78, juga disampaikan bahwa Allah sekali-kali tidak menjadikan untuk kamu dalam agama suatu kesempitan.

2) Dilaksanakan secara berjamaah, sedangkan jumlah jamaah tidak ada ketentuan dari Rasulullah saw.;

3) Dilaksanakan pada waktu shalat Dhuhur, sebagaimana yang dilakukan Rasulullah saw. sebagaimana disabdakan Rosulullah SAW yang artinya;

Rasulullah saw. shalat Jum'at ketika matahari telah tergelincir. (H.R.alBukhari dari Anas Ibn Malik)

4) shalat Jum'at diawali dengan dua khotbah.

Dalam sebuah hadits, diriwayatkan sebagai oleh Muslim yaitu dari lbnu Umar berknta, " Rasulullah saw. berkhotbah pada hari Jum'at sambil berdiri kemudian duduk kemudian berdiri. (H.R. Muslim: 1420). 
Diterbitkan oleh Fakultas Sastra dan Budaya

Universitas Ahmad Dahlan Yogyakarta

c. Rukun Shalat Jum'at

Rukun shalat Jum'at sama dengan rukun shalat fardu. Rukun shalat Jum'at adalah sebagai berikut:

1) khatib (lazimnya sekaligus menjadi imam),

2) jamaah Jum'at,

3) dua khotbah atau khotbah dua kali dan duduk di antara keduanya, dan

4) shalat dua rakaat (shalat Jum'at) dengan

berjamaah. d. Sunah Shalat Jum'at

Beberapa hal yang disunahkan bagi orang yang akan melaksanakan shalat Jum'at, antara lain:

1) mandi sebelum berangkat ke masjid,

2) memakai pakaian yang paling bagus (jika ada), dan

3) memakai harum-haruman (kecuali bagi wanita).

4) bersiwak atau sikat gigi. Rasulullah saw bersabda yang artinya: Sepantasnyalah tiap muslim itu mandi dan berharum-haruman serta menggosok gigi pada hari Jum'at. (H.R. Ahmad dari Syaikh:21998).

5) Tidak makan dan tidak tidur siang dulu kecuali setelah shalat jumat.

6) Hal-hal yang disunahkan tersebut menunjukkan bahwa shalat Jum'at hendaknya dilaksanakan secara tertib, bersih, dan rapi sehingga sedap dipandang mata. Selain itu, pelaksanaan ibadah dalam suasana yang baik seperti itu dapat menjadi daya tarik tersendiri bagi masyarakat. Dengan demikian, amalan sunah dapat berfungsi sebagai sarana dakwah Islamiah.

e. Beberapa Hal yang Membatalkan Shalat Jum'at dan Pahala Shalat Jum'at.

Ada beberapa hal yang membatalkan shalat Jum'at. Beberapa hal tersebut yaitu:

1) Semua hal yang membatalkan shalat fardu;

2) Bercakap-cakap antara sesama jamaah; mengingatkan atau menegur jamaah lain yang sedang bercakap-cakap. Rasulullah saw. bersabda, yang artinya:

Barang siapa berbicara pada hari Jum'at, sedangkan imam berkhotbah maka dia bagaikan himar yang membawa kitab, sedangkan orang yang mengucapkan kata-kata " diamlah" maka tidak dianggap Jum'at. (H.R. Ahmad, Ibnu Syaibah, Bazar, dan Tabrani).

3) Khotbah Jum'at. Tidak sah apabila shalat Jum'at tidak diawali dengan khotbah Jum'at. Rasulullah saw menyatakan bahwa orang yang berbicara atau memperingatkan orang yang bercakap-cakap saat khotbah berlangsung dinyatakan tidak ada shalat Jum'at baginya. Dengan kata lain, shalat Jum'at yang dilakukan tidak diperhitungkan sehingga tidak mendapatkan pahala dari sisi Allah swt.

\section{Khotbah Jum'at}

Secara harfiah khutbah berarti ceramah atau pidato. Jadi, khotbah Jum'at pada hakekatnya adalah pidato tentang seruan kebaikan sebagaimana diajarkan dalam agama Islam sebagai rangkaian shalat Jum'at. Khotbah Jum'at dilaksanakan sebelum shalat Jum'at

Penggunaan Multi Media untuk 37 Meningkatkan Efektivitas Pesan Khutbah Jumat 
dimana waktu pelaksanaan khutbah jumat tersebut sama dengan waktu pelaksanaan shalat Dhuhur.

Pelaksanaan kutbah jumat dilakukan sebanyak dua kali, yaitu khutbah pertama dan kedua. Di antara khutbah pertama dan kedua, khatib menyelinginya dengan duduk sebentar dan membaca shalawat atau surah al-ikhlas. Adapun jamaah yang sedang mengikuti khutbah, hendaknya memperhatikan khutbah dengan sebaik-baiknya dan tidak boleh berbicara apalagi bersuara berisik.

\section{Hakekat Tujuan Khutbah Jumat}

a. Hakekat Tujuan Khutbah Jumat

Dalam istilah fiqih, khutbah adalah ceramah yang diucapkan atau dibacakan di depan sejumlah orang. Dari pengertian ini, ada banyak macam khutbah. Yaitu khutbah yang dilakukan sebelum shalat Jumat, sebelum shalat id atau sebelum ija, dan qabul pernikahan. Dengan demikian, khutbah jumat adalah khutbah yang disampaikan pada hari Jumat saat waktu shalat dhuhur. Secara umum, tidak ada perbedaan antara khutbah dengan ceramah. Isi pesan khutbah adalah nasehat dan tuntunan keagamaan guna memperteguh keimanan serta ketaqwaan kepada Allah SWT.

Khutbah mempunyai kedudukan yang penting dalam agama Islam. Oleh karena itu, khutbah harus disampaikan dengan bahasa yang jelas, baik, halus, lancar teratur serta ungkapan yang mudah dimengerti, sehingga menyentuh jiwa dan perasaan hadirin. Pada hakekatnya, yujuan khutbah jumat adalah untuk memberikan nasehat kebaikan untuk meningkatkan iman dan takwa di kalangan jamaah.

\section{b. Syarat dan Rukun Khotbah Jum'at}

Khotbah Jum'at dilakukan sebelum shalat dikerjakan. Khotbah Jum'at baru dianggap sah apabila syarat dan rukun khotbah terpenuhi. Syarat khotbah Jum'at. Syarat khotbah Jum'at, dapat dituliskan sebagai berikut:

1) Niat

2) Khatib harus suci dari hadats dan najis,

3) Khatib harus menutup aurat,

4) Khotbah dimulai setelah masuk waktu shalat Dhuhur, namun dilakukan sebelum salat Jum'at,

5) Khotbah dilakukan dengan berdiri (jika mampu),

6) Khatib duduk sejenak antara dua khotbah,

7) Suara khatib terdengar oleh jamaah.

8) Disampaikan dengan bahasa yang bisa dipaham oleh Jamaah.

9) Antara khutbah satu dan khutbah dua dilakukan dalam satu waktu. (antara keduanya tidak boleh dipisahkan dengan salat Jum'at ).

c. Rukun Khotbah Jum'at

Rukun khotbah Jum'at yang harus dipenuhi bagi seorang khatib adalah sebagai berikut: 
Diterbitkan oleh Fakultas Sastra dan Budaya

Universitas Ahmad Dahlan Yogyakarta

1) Khatib harus mengucapkan tahmid (puji-pujian kepada Allah swt, dengan membaca "al-hamdulillah, atau, ahmadullah, atau hamdan lillah, dan sesamanya") dalam setiap khutbah pertama dan kedua.

2) Khatib harus mengucapkan solawat atas Nabi Muhammad saw. dalam setiap khutbah, satu dan dua (salawatnya: "Allahumma sholli 'ala Muhammad, dan atau semacamnya"). Perkataan Umar bin Khottob Radhiallahu 'anhu, "Sesungguhnya doa itu terhenti di antara langit dan bumi, tidak akan naik sedikitpun dari tempat itu sampai engkau bershalawat atas Nabimu Muhammad Shallallahu 'alaihi wasallam (HR. Tirmidzi no.486 dan Silsilah Ash-Shahihah karya syaikh Nashiruddin Al-Albani no.2035).

3) Khatib harus mengucapkan dua kalimah syahadat. Dari Abu Hurairah Radhiallahu 'anhu dari Nabi Shallallahu 'alaihi wasallam beliau bersabda, yang artinya, setiap khotbah yang tidak dibaca syahadat di dalamnya bagaikan tangan yang terpotong. (H.R. Abu Dawud dari Abu Hurairah nomor 4201).

4) Khatib berwasiat untuk jamaah tentang ketakwaan dan hal yang dipandang perlu sesuai kondisi jamaah dalam setiap khutbah, yaitu dengan menyampaikan pesan "ittaqullah, atau athi'ullah, atau ushikum bitaqwallah, dan atau semisalnya." Wasiat yang dimaksudkan ialah bahwa khotib berwasiat kepad kaum muslimin yang mendengarkan agar bertakwa kepada Allah. Dari Jabir bin Samurah Radhiallau 'anhu, dia berkata,"Sholat Rasulullah Shallallahu 'alaihi wasallam adalah sedang - sedang saja dan khutbah beliau juga sedang-sedang saja; dimana beliau membaca ayat-ayat dari Al-Qur'an dan mengingatkan manusia" (HR.Abu Dawud no.1094).

5) Khatib membaca satu atau sebagian dari ayat Al-Qur'an pada salah satu khotbah. Diriwayatkan oleh Muslim (HR Muslim nomor 862) dimana Jabir bin Samurah Radhiallahu 'anhu, menyampaikan bahwa Nabi Muhammad Shallallahu 'alaihi wasallam menyampaikan dua khutbah dimana beliau duduk di antara keduanya; (dan dalam khutbah itu) beliau membaca AlQur'an dan mengingatkan manusia”.

6) Khatib berdoa yang ditujukan kepada muslimin dan muslimat yang berisi permohonan ampun atas segala dosa. Doa untuk kebaikan dan ampunan bagi orang-orang beriman pada khutbah kedua.

Dalam Mazhab Syafi'I, semua rukun khutbah harus disampaikan dalam bahasa Arab, namun pesan-pesan lain yang tidak termasuk dalam rukun khutbah bisa disampaikan dengan bahasa yang dipahami oleh jamaah. Menurut mazhab Hanafi, rukun khutbah adalah satu yaitu dzikir baik panjang maupun pendek. Menurut Mazhab Hanafi, bahkan bacaan tahmid, tasbih, atau tahlil, sudah cukup menggugurkan kewajiban khutbah. Menurut Mazhab Hanafi, khutbah bisa disampaikan dalam bahasa apa saja, tidak semuanya harus bahasa Arab.

Sementara itu dalam mazhab Maliki, rukun khutbah adalah satu, yaitu ungkapan yang memuat kabar gembira (dengan janji-janji pahala dari Tuhan) atau peringatan (bagi orang-orang yang suka melanggar aturan Tuhan). Mazhab ini berpendapat bahwa 
keseluruhan khutbah harus disampaikan dalam bahasa Arab. Jika tidak ada yang mampu menggunakan bahasa Arab maka kewajiban salat Jum'at gugur untuk dilaksanakan.

Dalam mazhab Hanbali, rukun khutbah ada empat, yaitu:

1) Bacaan "alhamdulillah" dalam setiap khutbah, satu dan dua.

2) Salawat atas Nabi Muhammad.

3) Membaca satu atau sebagian ayat al-Qur'an.

4) Wasiat untuk melakukan ketakwaan.

5) Disampaikan dalam bahasa Arab bagi yang mampu. Bagi yang tak bisa berbahasa Arab maka menggunakan bahasa yang dimampui, khusus untuk ayat al-Qur`an tidak boleh digantikan dengan bahasa lain.

\section{Adab Ketika Khotbah Sedang Berlangsung}

Selama khotbah berlangsung, jamaah hendaknya bersikap sebagai berikut:

1) Jamaah tenang mendengarkan khotbah dan duduk menghadap ke arah kiblat. Dalam harist riwayat Ibnu Majjah, disampaikan bahwa ketika Rasulullah saw. berdiri di atas mimbar, para sahabat menghadapkan wajahnya ke arah beliau. (H.R. Ibnu Majjah dari Adiyy ibn Sabit dari Ayahnya: 1126).

2) Tidak berbicara selama khotbah berlangsung. Berbicara pada saat khotbah dapat merusak ibadah itu sendiri dan mengganggu jamaah lain yang hendak mendengarkan khotbah,sehingga memperoleh dosa. Disampaikan oleh Rasulullah saw. Bahwa bila engkau berkata kepada kawanmu pada hari Jum,at dengan kata-kata "diamlah", sedangkan saat itu khatib sedang berkhotbah maka sungguh engkau "laga" (sia-sia) shalat Jum'at. (H.R. alBukhari dari Abu Hurairah: 882).

3) Jamaah berdoa atau membaca istigfar saat khatib duduk di antara dua khotbah. Waktu di antara dua khotbah merupakan waktu dikabulkannya doa (waktu ijabah). Sebelum duduk, khatib akan mengucapkan doa yang artinya mohonlah ampun kepada Allah, sesungguhnya Dia Maha Pengampun lagi Maha Penyayang. Atau doa yang artinya katakanlah! "Wahai Rabb-ku! Ampuni dan kasihilah (aku)! Engkau sebaik-baik yang menyayangi."

\section{Komunikasi Efektif}

Komunikasi efektif yaitu komunikasi yang mampu menghasilkan perubahan sikap (attitude change) pada orang lain yang bisa terlihat dalam proses komunikasi. Khutbah Jumat sebenarnya merupakan proses komunikasi dari khatib pada komunikan, yaitu jamaah shalat jumat. Idealnya khutbah jumat merupakan wujud komunikasi efektif. Yaitu komunikasi dimana antara komunikator dan komunikan sama-sama memiliki pengertian yang sama tentang suatu pesan. Komunikasi efektif ditandai dengan adanya pengertian, dapat menimbulkan kesenangan, mempengaruhi sikap, meningkatkan hubungan sosial yang baik, dan pada akhirnya menimbulkan suatu tindakan (Jalaluddin Rakhmat, 1996).

Menurut Mc. Crosky Larson dan Knapp, komunikasi efektif dapat dicapai dengan mengusahakan ketepatan (accuracy) antara komunikator dan komunikan dalam setiap 
Diterbitkan oleh Fakultas Sastra dan Budaya

Universitas Ahmad Dahlan Yogyakarta

komunikasi. Ketepatan yang dimaksud berarti pesan yang digunakan oleh komunikator tersebut dikuasai oleh komunikannya.

Komunikasi yang lebih efektif terjadi apabila komunikator dan komunikan terdapat persamaan dalam pengertian, sikap dan bahasa. Komunikasi dapat dikatakan efektif apa bila komunikasi yang dilakukan dimana:

1) Pesan diterima dan dimengerti serta dipahami sebagaimana yang dimaksud oleh pengirimnya.

2) Pesan yang disampaikan oleh pengirim dapat disetujui oleh penerima dan ditindaklanjuti dengan perbuatan yang diminati oleh pengirim.

3) Tidak ada hambatan yang berarti untuk melakukan apa yang seharusnya dilakukan untuk menindaklanjuti pesan yang dikirim.

Komunikasi efektif merupakan kondisi dimana tiap pelaku komunikasi yaitu antara komunikator dan komunikan sama-sama mengerti apa pesan yang disampaikan. Kondisi saling memahami ini, disebut dengan "the communication is in tune".

Ada sejumlah syarat agar komunikasi dapat berlangsung secara efektif (http://edoparnando27.wordpress.com/komunikasi-efetif/), yaitu sebagai berikut:

1) Menciptakan suasana yang menguntungkan.

2) Menggunakan bahasa yang mudah ditangkap dan dimengerti.

3) Pesan yang disampaikan dapat menggugah perhatian atau minat di pihak komunikan.

4) Pesan dapat menggugah kepentingan dipihak komunikan yang dapat menguntungkannya.

5) Pesan dapat menumbuhkan penghargaan atau reward di pihak komunikan.

Munculnya minat komunikan terjadi bila pesan yang disampaikan itu menarik

minat, terdapat kontras, ada yang menonjol serta ada harapan khalayak memperoleh keuntungan. Johnson, Sutton dan Harris (2001:81-82) menunjukkan serangkaian cara agar komunikasi dapat efektif dicapai. Menurut mereka, salah satu hal penting agar membuat komunikasi dapat efektif adalah dengan memperhatikan tentang pesan (message) dan bagaimana pesan tersebut dikirimkan (delivery channel atau media). Komunikasi efektif dapat dilakukan oleh setiap orang, termasuk oleh khatib yang memberikan khutbah jumat. Melatih berkomunikasi efektif perlu dilakukan dengan pembiasaan dan praktek.

Komunikasi efektif memiliki manfaat yang sangat menguntungkan karena mampu memberikan kemudahan bagi pelaku komunikasi yang terlibat dalam proses komunikasi dalam memahami pesan. Selain itu, komunikasi efektif juga dapat membuat komunikasi berjalan tidak monoton.

\section{Penggunaan Multi Media dalam Khutbah Jumat}

Multimedia adalah penggunaan teknologi elektronik computer untuk menyajikan dan menggabungkan teks, suara, gambar, animasi, audio, dan video degan alat bantu (tools) dan koneksi (link) sehingga pengguna dapat melakukan navigasi berinteraksi, berkarya dan berkomunikasi.

Dewasa ini, multimedia digunakan secara luas untuk membantu manusia menyampaikan pesan secara lebih kreatif, menarik dan efektif. Multi media tersebut 
digunakan pada semua bidang, termasuk dalam dunia pendidikan dan pengajaran serta bisnis. Umumnya, komunikasi yang menggunakan multimedia dapat mendorong efektifitas hasil. Oleh karena itu, multimedia akhirnya juga digunakan secara luas, termasuk dalam bidang syiar Islam.

Ada banyak kegiatan syiar Islam yang dilakukan oleh umat Islam. Salah satunya adalah penyampaian pesan kebaikan dalam khutbah jumat. Bila selama ini khutbah jumat disampaikan secara tradisional, yaitu hanya sekedar memenuhi sunah dan syah khutbah, maka sudah selayaknya sekarang ini, khotbah jumat dilakukan revitalisasi agar efektifitas pesan dalam khutbah dapat lebih meningkat. Dengan revitalisasi khutbah jumat ini, maka pemahaman tentang keagamaan diyakini dapat meningkat lebih baik yang pada gilirannya pembangunan mental masyarakat dapat makin mudah diwujudkan. Tentu saja, revitasliasi yang dimaksud dengan tetap tidak melanggar syarat dan syah pelaksanaan khutbah itu sendiri.

Dari pengalaman penulis saat mengikuti shalat jumat dimana khotbah disampaikan menggunakan bantuan multimedia, diperoleh banyak perbedaan dibanding shalat jumat dengan khutbah jumat 'konvensional' yang tidak menggunakan multimedia. Shalat jumat dimana khutbah disampaikan dengan bantuan multimedia yang diikuti oleh penulis tersebut diselenggarakan pada tanggal 31 Oktober 2014 di Gedung Taman Budaya Yogyakarta, bertepatan dengan Festival Pinastika, yaitu forum ajang kreativitas para pekerja periklanan se-Indonesia, dengan khotib Sdr. Andika Dwijatmiko, S.Sn.

Pada pelaksanaan shalat jumat tersebut, tema khutbah diberi judul "Dari Iman Gratisan menuju Iman yang Membawa Perubahan." Dalam khutbah tersebut disampaikan bahwa banyak umat Islam khususnya di Indonesia yang menganut agama Islam karena keturunan, padahal banyak masyarakat di Barat yang masuk Islam karena dasar pembuktian kebenaran ilmiah.

Multimedia yang ditampilkan oleh khatib terdiri atas unsur gambar foto, grafis, warna, tulisan, dan penggalan-penggalan ayat Al-Quran. Teknik presentasi pergantian antar frame tayangan menggunakan animasi. Teknik penyampaian pesan dilakukan dengan pendekatan campuran, baik emosional, rational, dan normative approach sekaligus. Pesan yang disampaikan yaitu tentang penciptaan alam semesta, penciptaan manusia, mengapa babi diharamkan, hasil peneitian tentang cara penyembelihan binatang menurut Islam dan dunia barat, dan fakta penemuan Mummy Fir'aun. Semua materi dikaji menurut kebenaran ilmiah, dimana semua hal tersebut ternyata telah disampaikan dalam Islam. Kebenaran-kebenaran ilmiah inilah yang banyak membuat masyarakat barat masuk Islam.

Gambar 1. Beberapa contoh presentasi khutbah jumat multi media yang digunakan oleh Sdr. Andika Dwijatmiko, S.Sn. 
Diterbitkan oleh Fakultas Sastra dan Budaya

Universitas Ahmad Dahlan Yogyakarta

Dari pengamatan atas pelaksanaan shalat jumat dengan bantuan multimedia, semua jamaah jumat relative lebih memperhatikan pesan khutbah. Multimedia yang dipersiapkan oleh khotib, sangat menarik. Kemenarikan khutbah ditandai dari tidak adanya jamaah yang tertidur seperti yang biasa terjadi dalam khutbah jumat pada umumnya. Khatib melengkapi pesan khutbah dengan gambar foto, warna, dan tulisan yang menarik. Multimedia tersebut ditayangkan dengan menggunakan bantuan seperangkat alat projector (LCD). Presentasi tersebut disampaikan dengan runtut. Semua tayangan dijelaskan dengan baik dan sebaliknya, semua uraian verbal juga dikuatkan dengan visualisasi tayangan.

Dalam akhir tayangan, khotib tersebut juga menuliskan sumber-sumber pustaka dan informasi yang dirujuk. Karena banyak menggunakan media internet, maka pada bagian akhir, khatib tersebut banyak menampilkan situs internet, dimana sumber informasi, gambar, maupun keterangan lainnya diambil.

\section{E. Pedoman Khutbah Jumat Multi Media}

Penggunaan multi media dalam khutbah jumat perlu memperhatikan pedoman khusus, yaitu harus tetap memenuhi sejumlah syarat dan rukun khutbah jumat itu sendiri, dimana syarat khotib dalam khutbah jum'at tetap harus memulainya dengan niat; suci dari hadats dan najis; menutup aurat; dimulai setelah masuk waktu shalat Dhuhur, namun dilakukan sebelum salat Jum'at; dilakukan dengan berdiri (jika mampu); duduk sejenak antara dua khotbah; melantangkan suara hingga terdengar oleh jamaah; menyampaikan khutbah dengan bahasa yang bisa dipaham oleh Jamaah; menyampaikan khutbah satu dan khutbah dua dilakukan dalam satu waktu (antara keduanya tidak boleh dipisahkan dengan salat Jum'at ).

Khutbah jumat multimedia harus memenuhi rukun Khotbah Jum'at, yaitu; harus mengucapkan tahmid (puji-pujian kepada Allah swt, dengan membaca "al-hamdulillah, atau, ahmadullah, atau hamdan lillah, dan sesamanya") dalam khutbah pertama dan kedua; harus mengucapkan solawat atas Nabi Muhammad saw, dalam setiap khutbah baik satu dan dua (salawatnya: "Allahumma sholli 'ala Muhammad, dan atau semacamnya"). Perkataan Umar bin Khottob Radhiallahu 'anhu, "Sesungguhnya doa itu terhenti di antara langit dan bumi, tidak akan naik sedikitpun dari tempat itu sampai engkau bershalawat atas Nabimu Muhammad Shallallahu 'alaihi wasallam (HR. Tirmidzi no.486 dan Silsilah Ash-Shahihah karya syaikh Nashiruddin Al-Albani no.2035); dan harus mengucapkan dua kalimah syahadat. Dari Abu Hurairah Radhiallahu 'anhu dari Nabi Shallallahu 'alaihi wasallam beliau bersabda, yang artinya, setiap khotbah yang tidak dibaca syahadat di dalamnya bagaikan tangan yang terpotong. (H.R. Abu Dawud dari Abu Hurairah nomor 4201); berwasiat untuk jamaah tentang ketakwaan dan hal yang dipandang perlu sesuai kondisi jamaah dalam setiap khutbah, yaitu dengan menyampaikan pesan "ittaqullah, atau athi'ullah, atau ushikum bitaqwallah, dan atau semisalnya." Wasiat yang dimaksudkan ialah bahwa khotib berwasiat kepad kaum muslimin yang mendengarkan agar bertakwa kepada Allah. Dari Jabir bin Samurah Radhiallau 'anhu, dia berkata,"Sholat Rasulullah Shallallahu 'alaihi wasallam adalah sedang - sedang saja dan khutbah beliau juga sedang-sedang saja; dimana beliau membaca ayat-ayat dari Al-Qur'an dan mengingatkan manusia" (HR.Abu Dawud no.1094); membaca satu atau sebagian dari ayat Al-Qur'an pada salah 
satu khotbah. Diriwayatkan oleh Muslim (HR Muslim nomor 862) dimana Jabir bin Samurah Radhiallahu 'anhu, menyampaikan bahwa Nabi Muhammad Shallallahu 'alaihi wasallam menyampaikan dua khutbah dimana beliau duduk di antara keduanya; (dan dalam khutbah itu) beliau membaca Al-Qur'an dan mengingatkan manusia"; berdoa yang ditujukan kepada muslimin dan muslimat yang berisi permohonan ampun atas segala dosa pada khutbah kedua.

Selain itu, khutbah jumat multi media juga harus mendukung agar jamaah memenuhi sejumlah adab mengikuti shalat jumat. Ini berarti materi multimedia yang ditayangkan dalam khutbah multimedia, harus dalam batas-batas yang mampu menjaga jamaah untuk tetap tenang dan tidak mundang komentar (berbicara) selama khotbah berlangsung. Misalnya dengan menampilkan gambar maupun yang terlalu dramatis, mengundang kelucuan, pornografi, pornoaski, sarkasme (kekerasan), dan sebagainya.

Mengingat khutbah jumat merupakan khutbah yang khusus, maka ada baiknya batasan materi diatur secara rinci oleh pihak-pihak yang memiliki otoritas dalam urusan pembinaan mental dan perikehidupan beragama. Misalnya dari orginisasi Majelis Ulama Indonesia (MUI), Persyarikatan Muhammadiyah, Nahdlatul Ulama, Al Irsyad, dan sebagainya. Dari musyawarah atas berbagai organisasi tersebut, diharapkan dapat menghasilkan panduan yang jelas bagi batasan khutbah jumat multimedia.

\section{F. Kualitas Khatib}

Melakukan presentasi dengan menggunakan multimedia, memerlukan kemampuan pengetahuan dan keterampilan tersndiri. Oleh karena itu, penggunaan multimedia dalam presentasi komunikasi khutbah jumat mengharuskan khatib mempersiapkan diri secara lebih dibanding saat menyampaikan khutbah dalam kegiatan lain. Khatib harus melakukan sejumlah persiapan khusus atas materi yang akan disampaikannya di hadapan jamaah shalat jumat.

Ada dua kualifikasi yang diperlukan oleh seorang khatib yang akan memberikan khutbah jumat. Pertama, seseorang yang akan menjadi khotib shalat jumat harus memenuhi syarat sebagai khatib shalat jumat. Kualifikasi pertama tersebut merupakan syarat mutlak yang tidak boleh diabaikan. Tanpa kualifikasi tersebut, seseorang tidak boleh menjadi khatib. Menyangkut hal ini, maka ada baiknya diterapkan semacam sertifikasi khatib shalat jumat. Seseorang yang belum memiliki sertifikasi sebagai khatib, tidak boleh memberikan khutbah dalam shalat jumat, meskipun boleh memberikan ceramah dalam kegiatan lain, misalnya pengajian-pengajian. Bahkan dalam ceramah di pengajian-pengajian tersebut, sekaligus menjadi sarana latihan sebagai khatib shalat jumat.

System pemberian sertifikasi sebagai khatib khutbah jumat multimedia, jangan sampai rumit. Misalnya dengan kewajiban sejumlah biaya untuk mendapatkan sertifikat tersebut; memerlukan waktu yang terlalu lama untuk mengurusnya; birokrasi yang lama dan berbelit; tempat yang terlalu jauh, dan sebagainya. Dengan system yang sederhana, mudah, dan murah maka tidak akan menghalangi seseorang untuk mendapatkan sertifikat keahlian sebagai khatib shalat jumat multimedia. 
Diterbitkan oleh Fakultas Sastra dan Budaya

Universitas Ahmad Dahlan Yogyakarta

Kualifikasi kedua dari khatib khutbah jumat multimedia, adalah orang tersebut harus memiliki pengetahuan dan kemampuan praktis menyusun dan mempresentasikan materi multimedia.

Khatib tidak boleh gagap teknologi. Khatib harus mampu menguasai multimedia, minimal teknik pengoperasiannya. Sebelum naik mimbar, khatib harus melihat semua tayangan multimedia yang digunakan agar komunikasi verbal dalam khotbah jumat yang dilakukan dapat singkron dengan tayangan multimedia tersebut.

Khatib harus mampu mengembangkan kreatifitasnya dalam menyusun materi presentasi dan dituntut mampu mengoperasikan teknologi multimedia itu sendiri. Selain tentang multimedia, dan kemampuan dan pengetahuan tentang internet juga akan sangat membantu refitalisasi khutbah jumat. Bahkan melalui internet, Khatib dapat lebih babas dan mudah dalam menyiapkan bahan khutbah. Namun kemampuan penguasaan teknologi multimedia tersebut tidak boleh merusak syarat syah dan rukun khutbah shalat jumat itu sendiri.

Tentang materi khutbah, khatib dapat menyusun materi sendiri atau dapat saja dibuatkan oleh pihak lain. Sama dengan yang biasa dijumpai di tengah masyarakat, dimana di pasaran tersedia materi khutbah jumat, baik dalam bentuk buku, fotokopi, maupun digital yang diunduh dari internet. Meski demikian, presentasi dengan menggunakan multimedia, mengharuskan khotib tetap harus melakukan persiapan, setidaknya membaca terlebih dahulu presentasi yang dimaksud. Hal ini dimaksudkan agar apa yang dicantumkan dalam presentasi multimedia dapat secara tepat dikuasai dalam penyampaian komunikasi verbal pada saat khutbah.

Kemampuan teknik presentasi sangat diperlukan oleh khatib yang memberikan khutbah jumat multimedia. Yaitu mengatur agar tiap tayangan presentasi dapat terkesan menarik, membangkitkan semua jamaah shalat jumat untuk tetap terjaga dan menyimak pesan khutbah. Dalam satu frame tayangan, perlu diatur agar tampilan tidak berjubel, dimana tayangan tersebut cukup dapat dilihat oleh jamaah yang berada di bagian belakang.

\section{G. Penutup}

Revitalisasi atas khutbah jumat perlu dilakukan agar pesan dapat lebih efektif mencapai keberhasilan yang diinginkan. Revitalisasi khutbah yang dimaksud adalah dalam aspek metode penyampaian pesan dan teknik pendekatan penyampaian pesan. Teknik-teknik presentasi dalam ilmu komunikasi perlu digunakan. Bentuk revitalisasi khutbah jumat adalah dengan penggunaan multimedia. Perubahan tersebut perlu dilakukan agar pesan dapat lebih menarik dan pada gilirannya dapat lebih berpengaruh pada khalayak. Penggunaan multimedia yang menarik pada gilrannya dapat menaikan perhatian jamaah shalat jumat untuk menyimak pesan hutbah jumat secara lebih seksama. Dengan meningkatnya perhatian tersebut, diharapkan pesan dapat mencapai sasaran secara lebih efektif.

Penggunaan multimedia dalam khutbah jumat mengharuskan khatib khutbah jumat untuk mampu mengembangkan kreatifitasnya dalam menyusun materi presentasi. Namun dalam penyampaian pesan khutbah jumat menggunakan multimedia tersebut, khatib tetap harus menjaga agar pesan kebaikan tersebut tidak mengurangi rukun dan syarat syah

Penggunaan Multi Media untuk 95 Meningkatkan Efektivitas Pesan Khutbah Jumat 
khutbah jumat. Untuk keperluan ini, lembaga-lembaga terkait misalnya MUI, Persyarikatan Muhammadiyah, Nahdlatul Ulama, Al Irsyad, dan lain-lain, termasuk lembaga perguruan tinggi keagamaan bisa terlibat memberikan pelatihan-pelatihan. Yaitu baik pelatihan tentang penggunaan teknologi multimedia maupun pelatihan tentang batas-batas isi pesan komunikasi apa saja yang diperbolehkan ditampilkan dalam khutbah jumat, agar khutbah jumat dan shalat shalat jumat tetap khusus dan syah menurut Islam.

\section{Sumber Pustaka}

\section{Al-Quran}

Amir Syarifuddin, 2010, Garis-garis Besar Fiqh, Jakarta: Kencana.

Andika Dwijatmiko, Materi khutbah Shalat Jumat tanggal 31 Oktober 2014 di Taman Budaya Jogjakarta.

Arif Hanafi, Pembelajaran Mata Pelajaran Fiqih Kelas VII Semester Genap, Departemen Agama Madrasah Tsanawiyah (MTs) Propinsi Jawa Tengah 2009.

http://ashidiqkumpulanhadits.blogspot.com/2011/12/shalat.html, diakses pada tanggal 1 November 2014

http://edoparnando27.wordpress.com/komunikasi-efetif/, diakses pada tanggal 4 November 2014

http://id.wikipedia.org/wiki/Baligh, diakses pada tanggal 5 November 2014 http://www.bps.go.id/tab_sub/view.php?tabel=1\&id_subyek=12, diakses pada tanggal 8

November 2014 http://www.konsultasisyariah.com/bolehkah-sholat-jumat-dikantor/, diakses pada tanggal

9 November 2014 http://www.pustakasekolah.com/pengertian-khutbahjumat.html\#ixzz3IOQcrU7r, diakses

pada tanggal 8 November 2014

Jalaluddin Rakhmat, 1986, Psikologi Komunikasi, Remaja Rosdakarya, Bandung Johnson, Daniel; Peter Sutton dan Neil Harris. 2001. Extreme Programming Requires Extremely Effective Communication.

McCroskey, J.C., Larson, C. E., \& Knapp, M. L., 1971, An introduction to interpersonal communication. Englewood Cliffs, N.J.: Prentice Hall

Saleh Al-Fauzan, 2006, Fiqih Sehari-hari, Jakarta: Gema Insani 